\title{
Regulation, Cross Border Migrants and the Choice of Remittance Channels in South Africa
}

\author{
Oludele Akinloye Akinboade ${ }^{1}$, Anrich Daseman ${ }^{1}$, Trevor Taft' ${ }^{1}$, Victor M.S. Molobi² \\ ${ }^{1}$ Gordon Institute of Business Science, University of Pretoria, South Africa \\ 2RITR, University of South Africa, South Africa \\ Profolu01@gmail.com, anrich.daseman@resbank.co.za, taftt@gibs.co.za, molobvs@unisa.ac.za
}

\begin{abstract}
Remittances have become an increasingly important factor in developing economies. Among others, compliance with onerous regulation requirements discourages the use of formal methods of remittances. The paper discusses results from a survey of the influence of regulation on the choice of migrants' remittance channels in South Africa. It aims to highlight how regulation affects the choice between formal and informal channels of remitting funds. A questionnaire was administered to collect primary data from migrants seeking documentations from the Department of Home Affairs, those remitting funds at taxi ranks or bus terminals, and those remitting through commercial banks and money transfer operators. 275 responses were analysed using a Likert rating scale format of 1 (highest) to 5 (lowest). Regulatory requirements of documentary evidence are an important factor influencing the choice of the remittance channel used. Documentation requirement in the formal market causes migrants to be ineligible for the formal channels of remittances and is a factor that influences the choice of remittance channel. Restrictive visa requirements could easily push migrants to become illegal aliens which further deny them access to formal remittance channels. The paper adds to the academic literature on the determinants of remittance channels in Africa. Understanding the relevant issues could assist regulatory authorities to restructure the remittance market with a view to encouraging migrant workers to enter the formal financial system.
\end{abstract}

Keywords: Migration; Formal and informal remittances, Choice of remittance channel; South Africa

\section{Introduction}

Regulation $^{1}$ of economic activity is a key issue confronting national Governments and supranational policymakers (OECD, 2003). There are many definitions of regulation, referring to the diverse set of instruments by which governments set requirements on enterprises and citizens.

"Any government measure or intervention that seeks to change the behaviour of individuals or groups. It can both give people rights (e.g. equal opportunities), and restrict their behaviour (e.g. compulsory use of seat belts)." (BRTF, 2003)

Regulation is: '...A set of 'incentives' established either by the legislature, Government, or public administration that mandates or prohibits actions of citizens and enterprises ... . Regulations are supported by the explicit threat of punishment for non-compliance" (OECD, 1994).

These definitions encompass all measures or interventions undertaken by Central and Local Government bodies which affect business activity. These include: taxation and financial reporting, employment and health and safety, trading standards and consumer rights, environmental protection, intellectual property, premises and planning rules, data protection and Transport. Government also supports a legal framework of contract and property rights, which both enables and constrains business activity (See Akinboade \& Kinfack, 2012).

Impact of regulation on cross border migrants in Southern Africa: The World Bank estimates that more than 247 million people or 3.4 percent of the world population, live outside their countries of birth (World Bank, 2016) .Stock of emigrants in Africa in 2013 was 23.2 million or 2.5 percent of population. The top 10 emigration countries were Somalia, Burkina Faso, Sudan, the Democratic Republic of Congo, Nigeria, Cote d'Ivoire, Zimbabwe, Mali, South Africa, South Sudan. South Africa attracts is a magnet for migrants from all over the continent who played an indispensible role in building South African infrastructure (Kotze \& Hill, 1997). They worked primarily in the mining sector. Post-independence African migrants have tended to be refugees and asylum-seekers. In 2012, 5.7\% of the South African population was foreign born, comprising legal and illegal immigrants (Statssa, 2012 a, b).Historically, the entry of non-nationals into the South African labour market has been governed by a dual system of control, sometimes referred to as the "two gates" system (Truen \& Chisadza, 2012). White migration was predominantly emphasised at the beginning of the

${ }^{1}$ SeeAkinboade, O.A \&Kinfack, E.C (2012) 
$20^{\text {th }}$ century. This was, for all intents and purposes, intended to attract British immigrants (see Kotze \& Hill, 1997). Black immigrants were necessary to cater for the booming mining industry. However, recent developments of the migration regulation have become tight in South Africa. In terms of the immigration laws of South Africa, the Aliens Control Act of 1991 was amended in 1995 in order to place greater emphasis on the skills and qualifications of potential immigrants applying for permits.

Peberdy (2010) notes that the immigration policy emphasizes the entry of skilled migrants This was due the growing concerns about a domestic shortage of skills and the high emigration rates of skilled professionals. In the light of this the Department of Home Affairs (DHA) specifies the objectives of the Immigration Act, 2002 (Act No. 13 of 2002), as implemented on 7 April 2003, to include regulating the influx of foreigners by facilitating foreign investment and attracting skilled and qualified foreigners to South Africa. Others are the facilitation and simplification of the issuance of permits promoting tourism to South Africa. When the Immigration Act of 2002 was amended in 2004, it further reinforced the country's determination to facilitate the entry of skilled migrants. Under the aforementioned "two gate" system, migrant workers with the right to enter and work were documented. This was the way the first and front gate was implemented for mainly the skilled migrants. They received either temporary permits (such as work permits), or permanent residency permits. This gate is governed by immigration laws. The alternative gate otherwise called the second or back gate was opened to cheap, black, migrant labour (see Segatti, 2011a,b). This gate is governed by bilateral treaties between the South Africa and southern African countries like Botswana, Lesotho and Swaziland (the BLS countries), and Mozambique.

Although unskilled and semi-skilled workers did not qualify for work permits, the Act did however recognise the international bilateral labour agreements especially with Southern African Countries. The mining and agricultural sectors retained their preferential access to unskilled contract labour from neighbouring states. These contract labourers would not however have access to the immigration system except through marriage, and would not be able to bring their families with them. Truen et al. (2005) in Table 1 developed a framework to estimate immigrants stock in South Africa based on the assumption that any economic migrant faces two key legal challenges, namely the issue of whether they have the legal right to enter the destination country, and then whether they have the legal right to stay and work.

Table 1: Analytical quadrants of immigrants in South Africa

\begin{tabular}{lll}
\hline & Right to enter & Right not to enter \\
\hline Right to stay and work & (1)Skilled migrants on work permits or & (1)Asylum seekers and refugees \\
other temporary residence permits & (have a legal right to enter, but \\
& (2)Contract migrants in mining or the & no entry permit at time of entry) \\
commercial farming sector & (2)Beneficiaries of immigration \\
& (3)Permanent residents & amnesties \\
No right to stay and work & (1)Mgrants that enter on a non-work & Irregular migrants (e.g. border \\
& related permit (e.g. visitors', study and jumpers) \\
& medical permits) and then are employed \\
without a work permit. & \\
(2)Migrants that enter legally but then & \\
fail to leave the country once their & \\
permits (study, visitors, etc.) expire. & \\
(3)Retrenched contract workers &
\end{tabular}

Source: Truen et al. (2005)

In Table 2, it is shown that immigrants typically enter South Africa as relatives of other immigrants. Strict regulation requirements for documentations means that only about $30 \%$ of immigrants from overseas countries, and $18 \%$ from Africa are successful in work permit applications. Zimbabweans, Nigerians and Kenyans are typically highly skilled and proficient in English and are hence highly successful in work permit applications compared with other African immigrants. Otherwise African immigrants typically apply for refugee status permits and are less successful in obtaining business permits. Not surprisingly, immigrants from Africa's conflict zones such as Somalia, Congo, Democratic Republic of Congo, and Rwanda are most successful in applying for refugee permits in South Africa. 
Table 2: Percentage distribution of the types of temporary residence permits by region and the ten leading countries in each region, 2013

\begin{tabular}{|c|c|c|c|c|c|c|c|c|c|c|c|}
\hline \multirow{2}{*}{$\begin{array}{l}\text { Region/Sub- } \\
\text { Region }\end{array}$} & \multicolumn{11}{|c|}{ Percentage distribution of Migrants Permit Categories } \\
\hline & Visitors & Work & Relatives & Study & Business & Medical & Waiver & $\begin{array}{l}\text { Retired } \\
\text { persons }\end{array}$ & Treaty & Exchange & Total \\
\hline Overseas & 34,1 & 30,0 & 22,6 & 6,4 & 2,6 & 0,4 & 2,3 & 1,4 & 0,1 & 0,1 & 100,0 \\
\hline Europe & 50,2 & 15,8 & 15,1 & 9,1 & 1,2 & 0,8 & 4,0 & 3,5 & 0,2 & 0,2 & 100,0 \\
\hline $\begin{array}{l}\text { North } \\
\text { America }\end{array}$ & 52,7 & 15,5 & 14,5 & 11,4 & 0,9 & 0,4 & 2,7 & 1,7 & 0,1 & 0,0 & 100,0 \\
\hline $\begin{array}{l}\text { Central and } \\
\text { South } \\
\text { America }\end{array}$ & 46,5 & 19,6 & 16,5 & 11,3 & 0,6 & 0,9 & 2,9 & 0,6 & 1,2 & 0,0 & 100,0 \\
\hline Australasia & 51,1 & 17,1 & 18,0 & 8,8 & 0,9 & 0,9 & 2,1 & 0,9 & 0,3 & 0,0 & 100,0 \\
\hline Middle East & 52,7 & 17,0 & 12,4 & 12,4 & 4,1 & 0,3 & 0,2 & 0,6 & 0,1 & 0,2 & 100,0 \\
\hline Asia & 23,3 & 39,3 & 27,7 & 4,2 & 3,4 & 0,2 & 1,5 & 0,4 & 0,0 & 0,0 & 100,0 \\
\hline Africa & 31,2 & 18,3 & 24,0 & 22,2 & 1,3 & 2,2 & 0,5 & 0,1 & 0,1 & 0,0 & 100,0 \\
\hline SADC & 29,1 & 21,1 & 21,7 & 24,5 & 0,3 & 2,5 & 0,6 & 0,1 & 0,0 & 0,0 & 100,0 \\
\hline $\begin{array}{l}\text { East and } \\
\text { Central } \\
\text { Africa }\end{array}$ & 30,0 & 14,7 & 21,2 & 27,3 & 3,6 & 2,5 & 0,5 & 0,1 & 0,0 & 0,0 & 100,0 \\
\hline West Africa & 38,0 & 12,5 & 30,4 & 14,7 & 2,6 & 1,3 & 0,4 & 0,0 & 0,1 & 0,0 & 100,0 \\
\hline North Africa & 26,0 & 21,8 & 34,0 & 13,6 & 2,7 & 0,4 & 1,1 & 0,0 & 0,4 & 0,0 & 100,0 \\
\hline Total & 33,3 & 23,8 & 9,5 & 19,0 & 0,0 & 14,3 & 0,0 & 0,0 & 0,0 & 0,0 & 100,0 \\
\hline & 32,5 & 23,6 & 23,4 & 15,1 & 1,9 & 1,4 & 1,3 & 0,7 & 0,1 & 0,0 & 100,0 \\
\hline
\end{tabular}

Source: Statssa (2015; p.42)

The Government of South Africa created in November 1994, fourteen units of a new police division called the Illegal Alien Tracing Unit in order to address the problem illegal international migration(Maharaj, 2009). The task of the Unit was to detect corruption, identify fraudulent documents, take action against employers and persons assisting foreigners, and to identify and apprehend illegal immigrants. This action placed additional hurdles on the possibility of getting the right documentation for migrants in the country.

Study Motivation: Understanding the relationship between migration and development is crucial to poverty reduction efforts and is also gradually influencing other policy areas, such as immigration policy and banking regulation (Bracking \& Sachikonye, 2010). Informal remittance channels tend to be popular in countries where the financial sector is weak, mistrusted, or missing altogether (as in countries in engaged in or emerging from conflict).They are also often chosen where banking and foreign exchange facilities are inadequate, inefficient or even destroyed altogether regardless of transaction costs (Puri \& Ritzema, 1999). This is not the case in South Africa where the financial sector is strong and well developed. However, regulatory controls could have impact on the ability of migrants to use formal remittance channels, and promote the use of informal channels instead. It is therefore important to examine these issues as part of the process of understanding how policies could enhance the developmental impact of migrant remittances. This is crucial if migration is to enhance poverty reduction through the generation of migrant remittances and contribute to economic growth in sending and receiving countries.

Research objective: This study seeks to determine the influence of regulations on migrant workers choice of cross border remittance channels as between opting for formal and/or informal channels. This is intended to develop a deeper understanding, from a remitter's perspective, of the channels used to remit money from South Africa to cross border destinations. A better understanding of migrant remittances will contribute to the dialogue between academics, policymakers, remittance service providers and migrant workers. This could possibly help to increase the remittance flows to the formal channels. The study only focussed on financial transfers and did not include the transfer of goods or services as part of remittances sent. The rest of the paper is organised as follows. Section two discusses remittances, their importance to African economies, and the formal as well as informal channels of transmission. It later highlights how regulation could have an influence on the choice of remittance channels. Section three is about the research method adopted. Results are presented in section four. The last section concludes the paper. 


\section{What are remittances?}

Daseman (2013) makes a detailed discussion of remittances, their importance to the economies of African countries and how regulations influence the choice of preferred channels. Remittances are funds transferred from migrants to their home country such as monetary or cash transfers and other transfers, and may include consumer goods, capital goods and skills and technological knowledge (Taylor \&Fletcher, 2007). Lucas \& Stark (1985) suggest that the primary intention for sending remittances is often to ensure that family members back home perform various care-taking services.

The importance of remittances in Africa: The volume of remittances to developing countries has grown significantly over the years, along with a sharp rise in value. In 2007, the aggregate remittances increased to US $\$ 240$ billion out of the global amount of US\$318 billion, up from US\$2.98 billion in 1975 and US\$90 billion in 2003 (Ratha \& Xu, 2008).The World Bank estimates that remittances to developing countries stood at $\$ 436$ billion in 2014, and would reach $\$ 440$ billion in 2015 (World Bank, 2015c).The African diaspora fuels the continents' budget to the tune of 5\% of its total GDP and may be between $\$ 120$ billion and 160 billion (Radlicki, 2015). Recent research shows that remittances are as important as direct investment flows and have grown at a faster rate than the amount of official development assistance (Bouoiyour and Miftah, 2015). They are a large and stable source of foreign currency and they behave very differently from foreign private capital flows (Bouoiyour \& Miftah, 2015).Official or recorded remittances have surpassed total amount of official development assistance and now represent approximately two-thirds of overall foreign direct investment (Acosta, Baerg, \& Mandelman, 2009). This contributes to almost two percent of the gross domestic product of developing countries and illustrates the importance of remittances as a valuable source of external funding for these countries (Acosta, Baerg, \& Mandelman, 2009). The total amount of remittances is considerably more than this figure, but is not recorded, as it is carried out through informal channels (Maphosa, 2005). Informal remittances amount to about 35 to 75 percent of official remittances to developing countries (Bracking \& Sachikonye, 2010).

According to the International Fund for Agriculture Development (IFAD), African remittance flows to and within the continent each amount to about $\$ 40$ billion per year. About three quarters of all these transfers are informal.Though these flows are under-reported, between 2000 and 2007, remittances to the continent increased by more than 141 percent, from US $\$ 11.2$ billion to nearly US $\$ 27$ billion. These amounts only reflect officially recorded transfers; the actual amounts including unrecorded flows through formal and informal channels are believed to be significantly larger. Recorded remittances are more than twice as large as official aid and nearly two-thirds of foreign direct investment flows to developing countries. In particular, remittance flows to Africa are grossly underestimated, with wide gaps in data reporting in many countries (Anyanwu \& Erhijakpor, 2010).

The effects of remittances: The beneficial and detrimental effects of migration and overseas remittances can be classified using three perspectives, namely at the macro or national level, at the community level and at the household level (Anyanwu \& Erhijakpor, 2010). At the macro or national level, one of the most significant benefits of the inflows of remittances to the country is that it increases the foreign exchange earnings of the labour exporting country (Daseman, 2013). In addition, workers' remittances exert a positive impact on the balance of payments of many developing countries, as well as promoting economic growth through their direct effects on savings and investment, and indirect effects through consumption. Remittances that raise the consumption levels of rural households might have substantial multiplier effects because they are more likely to be spent on domestically-produced goods. However, as far as countries with low gross domestic product figures are concerned, remittance receipts can distort the functioning of formal capital markets and also destabilise exchange rate regimes through the creation of parallel currency markets.

International remittances can also indirectly promote community development through spill-over mechanisms. Firstly, increased consumption of migrant households can generate multiplier effects. If recipient families increase their household consumption on local goods and services, this will benefit other members of the community through increases in demand, which stimulate local production, thereby promoting job creation and local development. Secondly, remittances are also found to support formation of small-scale enterprises, thereby promoting community development. International remittances ease credit 
constraints by providing working capital for the recipients to engage in entrepreneurial activities. This results in job creation and enhancement of the development of the remittance receiving country's community. Thirdly, remittances, especially through migrant associations, may also contribute to the creation of new social assets and services and the community's physical infrastructure, such as schools, health centres, roads and other community projects. Lastly, on the negative side, international remittances are found to increase income inequality, especially for rural dwellers.

At the household level, international remittances increase family incomes, thus raising consumption of both durable and non-durable goods and/or savings. In Africa, remittances are part of a private welfare system that transfers purchasing power from relatively richer to relatively poorer members of a family. They reduce poverty, smooth consumption, affect labour supply, provide working capital and have multiplier effects through increased household spending. For the most part, remittances seem to be used to finance consumption or investment in human capital, such as education, health and better nutrition. Remittances may also serve as capital for starting businesses. Thus, international remittances generally raise the immediate standard of living of recipient families. On the economic side, international remittances do promote idleness on the part of the recipients, as it may create a moral hazard problem, inducing disincentives to work. On the social side, it may increase family tensions within households, both among those at home and with migrants who are remitting money.

Formal remittance channels: Formal remittances refer to those remittances which enter into the economy through legitimate channels such as banksand non-bank financial institutions such as exchange bureaus,Money Gram, Western Union, etc (Sharif Mahmud, 2012). The transfers carried through money transfer operators (MTOs) and post offices are also included within the framework of formal transfers (Siegel \& Lucke, 2009). The formal channels are thus officially registered entities and as such any other remittance services are defined as informal channels (Kosse \& Vermeule, 2014). Regular remittances are more likely to go through officially recognised channels (Pieke, Van Hear, \& Lindley, 2007).In Kenya bank transfer services are used more than in Tanzania and Uganda for domestic and intraregional money transfers, including remittances, because Kenya has a relatively well developed banking industry (See Sander, 2004).In particular, less-skilled workers are more likely to go through officially recognised channels, possibly in part because they have fewer opportunities to return home with money and because their remittances are required more regularly by poorer and more dependent families, compared to the more skilled workers.

The importance of formalising remittance channels: Typical amounts sent for personal purposes range from $\$ 5$ to 500 and for small traders up to $\$-50,000$ per transaction (Sanders, 2004).Due to the size of this flows, the encouragement of greater remittance inflows through official banking channels is important for development. It enhances savings and enables better matching of savings and investment opportunities (Mookerjee \& Roberts, 2011). This is because remittances received as cash through unofficial channels are less likely to be saved than those received through bank accounts (Mookerjee \& Roberts, 2011). A way to improve remittance flows through official channels is to enhance financial sector development through increases in the number of banking institutions in developing countries and the number of bank branches (Mookerjee \& Roberts, 2011). The weaknesses in conventional financial system, such as high costs, poor or unavailable services and lack of access, steers remitters away from formal channels (Sharif Mahmud, 2012). Lower transaction costs can be achieved by increasing the number of banking institutions that offer remittance transfer services (Mookerjee \& Roberts, 2011). This generates greater competition and drives transaction costs down (Mookerjee \& Roberts, 2011).

The formalisation of remittances has the potential to introduce migrant workers and their families to the formal financial sector in both the sending and receiving countries (Ambrosius, Fritz, \& Stiegler, 2008). Remittances can provide a point of entry to the formal financial system for the unbanked population, providing them with access to bank accounts and other financial products such as consumer loans, mortgages, life and non-life insurance products and pensions (Ambrosius, Fritz, \& Stiegler, 2008). In addition remittance recipients usually demonstrate higher levels of account holding than the average population. An example of government initiatives to include undocumented working migrants in the formal system was the quasi-formalisation of migrants in the United States (Ambrosius, Fritz, \& Stiegler, 2008). This involved the issue of an identification document called 'Matrícula Consular de Alta Seguridad' (MCAS), to provide them access to the formal financial sector. Despite some criticisms, this alternative form of documentation became acceptable to a wide range of banks and other 
institutions in the United States, thus granting undocumented migrants access to financial services, including the sending of remittances. On the receiving side it provided access to micro-finance operators (MFOs) which had a broader footprint than traditional banks. Although they could not provide funds due to foreign exchange regulations, micro-finance operators accepted remittances as collateral for credits. The money transfer operators also collaborated with credit unions to provide a beneficiary account registration by which a remittance sender opened a bank account in the name of the recipient family member and the account was personally formalised when receiving the remittance (Ambrosius, Fritz, \& Stiegler, 2008).

Types of informal or alternative remittance transfer system: Informal remittance channels include those money transfers which occur through private, unrecorded and illegitimate channels. (Sharif Mahmud, 2012). The transfers carried out through the use of minibus operators, train conductors and bus drivers are some of the options used for informal remittances (Siegel \& Lucke, 2009). Informal channels also include remittances carried by friends or relatives or the migrant himself to destination countries (Sharif Mahmud, 2012). Informal remittance transfers can be made through a range of systems, encompassing the actors, institutions and procedures that transfer money from migrants to their families (Pieke, Van Hear, \& Lindley, 2007). Such systems may have a wide international reach and operate along corporate commercial lines. They may be organised among and specifically meet the demands of particular nationalities or ethnic groups, or they may be organised around more personalised connections with a particular locality in the country of origin. Some remittance systems are based on forms of value transfer without actually physically moving money. In value transfer systems, such as the hawala system used in the Horn of Africa, the Middle East, Pakistan and Afghanistan, and the hundi system used in South Asia, the customer gives money to an agent in the host country, who communicates to a corresponding agent in the country of origin the instruction to pay out the equivalent sum to a nominated individual. The agent makes money on the transaction through a fee or by other means. Other types of transfers outside the mainstream include hand carrying/couriering, money transfer as part of other businesses, dedicated money transmitters and systems associated with credit unions, micro-finance and insurance institutions (Pieke, Van Hear, \& Lindley, 2007).

Hand carrying: Hand carrying of cash remittances by migrants on a return visit is common. Customs restrictions, sanctions for non-compliance, customs corruption or crime in home countries may be factors in limiting the total amount of cash that migrants carry on return visits (World Bank, 2004). Certain categories of migrants are also less likely to return on visits, especially refugees and irregular migrants, who may not want to risk re-entry problems on return to the country of residence. Alternatively, instead of returning personally with funds, the migrant may trust a relative, friend or prominent person to deliver the money to recipients. Northern Sudanese and Congolese people in Europe reported the option, frequently taken, of going to the airport on the day of a homebound flight and asking a person from the check-in queue to take an envelope with cash along (Pieke, Van Hear, \& Lindley, 2007).Migrants may also use money-delivery services offered by transport companies to remit particularly within Africa. Taxis are sometimes used to send money home across borders in Southern Africa, with anecdotal evidence suggesting that drivers generally charge about 20 percent of the total transfer value to transport remittances from South Africa to neighbouring countries (Pieke, Van Hear, \& Lindley, 2007). Maphosa (2005) finds that the bulk of the value transferred from migrants in South Africa to a district of Matebeleland in Zimbabwe is transmitted in kind, in the form of products such as maize-meal, sugar, salt, cooking oil, consumer goods, and agricultural inputs and building materials. In East Africa, a number of buses, coach or courier companies offer money transfer or transport services for domestic or intra-regional transfers.

Hand carrying goods as gifts during return visits is common among all migrant groups. Bringing gifts is culturally significant, as it is considered a duty to friends and relatives and a sign of migratory success, and bringing goods as gifts may actually be preferred, especially in periods of economic crisis or financial breakdown (Pieke, Van Hear, \& Lindley, 2007). Hand carrying and couriering cash as remittance methods are poorly researched, meaning that the amounts involved are currently impossible to quantify. The lack of data here is remarkable considering the significance reported on this channel (Pieke, Van Hear, \& Lindley, 2007). A survey of return migrants in Ghana and the Ivory Coast about their previous remittance habits found that migrants on a return visit or relatives or friends delivered significant sums. Hand carrying in cash and kind to home countries may amount to as much as 25 percent of all informal remittances leaving the United 
Kingdom. Hand carrying seems to be particularly common in Africa in comparison with the rest of the world (Pieke, Van Hear, \& Lindley, 2007).

Remittance transfer in the context of other businesses: Cash-intensive businesses, particularly outlets with good international communications facilities, often offer remittance transfer services as a side-line (Pieke, Van Hear, \& Lindley, 2007). Transfer services may be offered from private residences and market stalls as well. Some such outlets conform to host-country and country-of-origin financial regulations, while others do not (Pieke, Van Hear, \& Lindley, 2007). The agents involved make money on the exchange-rate spread and often also from fees charged to the customer. Rigid foreign-exchange regulations in many countries mean that money can be made from exchanging remittances at black-market exchange rates or simply from exchange-rate speculation. Where there are strong exchange controls, there is high demand from importers for foreign exchange. Where there are strong tax regimes on imports, some importers are keen to under-invoice imports. These factors all encourage money transfer activity.

Senegalese people living in France, Italy, Spain, Belgium or Germany can contact a transnational Senegalese trader, and make an arrangement for the trader to pay an agreed amount to the migrant's family on the trader's return to Senegal (Pieke, Van Hear, \& Lindley, 2007). The migrant will repay the loan during the trader's next business trip to his or her country of residence. The advantage of this for traders is that they do not have to exchange currency in Senegal for the next trip because they expect to be repaid on their return to Europe. There are several variants on this practice, such as the migrant may approach the trader and make an arrangement for a business partner in Senegal to transfer money to the migrant's family, or the migrant may contact the trader while she or he is still in Senegal and make the arrangement in advance.

A further variation involves depositing money in advance of the transfer with the trader with an agreement on rates of exchange and details of the recipient (Pieke, Van Hear, \& Lindley, 2007). The trader can then use the money from the emigrant to purchase merchandise in Europe and elsewhere. On return to Senegal, the trader can both quickly sell his or her new merchandise and make the payment to the designated recipient. This system was very common in the 1980s and 1990s for Somali migrant workers in the Middle East transferring money back to Somalia in connection with the thriving livestock export trade from Somalia, to mutual benefit. It has become less common in the light of the rise of large, specialised Somali money transfer firms, which grew out of and eventually replaced such mechanisms (Pieke, Van Hear, \& Lindley, 2007).

Dedicated money transmitters: There are also dedicated money transmitters offering services from Europe and North America to African countries. They are in many ways direct competitors, albeit in niche markets, to the big mainstream companies, such as Western Union and MoneyGram. Many of these small-scale, local businesses have arisen from a specific group of migrants' remittance needs. An example, as taken from the Sudan case study by Riak Akuei (as cited by Pieke, Van Hear, \& Lindley, 2007), is that of a business established by two friends. The majority of clients are repeat customers, which make up almost $90 \%$ of the business. A file is kept for each person who requests a transfer. It contains their personal details and transaction histories. Anyone sending money must show valid identification, such as a passport and provide the name, address and telephone number for themselves and the intended recipients of the funds. The fee to send money to Sudan through this channel is $£ 5$ regardless of the amount. Upon receipt of the funds in London, a fax is sent to the office's agent in Khartoum. Pay out usually occurs within 24 hours in local currency. Periodically, the accumulated cash is taken to a person who works for a large company with foreign interests in Khartoum. The money is brought to the businessman about every two weeks who works for the company. Then the agent is notified, who goes to the subsidiary to pick it up. Some beneficiaries of remittances reside outside greater Khartoum. In order for funds to reach these recipients, the agent in Khartoum makes a domestic bank transfer without any fees deducted. The Asia Pacific Group (as cited by Pieke, Van Hear, \& Lindley, 2007) mentions that many of these dedicated, sophisticated money transmitters have established websites or advertise in telephone directories in both the ethnic and local press, and on the radio. Passas (as cited by Pieke, Van Hear, \& Lindley, 2007) indicates that both systems often rely on socially embedded mutual trust and common economic interest, which explains how some remittance systems can be based on forms of value transfer without actually transferring money simultaneously. It is important to note that many remittance transfer systems like this originate from small-scale arrangements between migrants and people at home cooperating in response to common interests. 
Other kinds of transfer mechanisms outside the mainstream: In recent years, some credit unions and microfinance institutions in areas of significant emigration and immigration have begun to offer remittance transfer services, sometimes in conjunction with large, mainstream operators (Pieke, Van Hear, \& Lindley, 2007). The World Council of Credit Unions (WOCCU) has been leading efforts to diversify credit unions into remittance transfer services, with the goal of using remittances to attract new members to credit unions, both immigrants and recipients (Pieke, Van Hear, \& Lindley, 2007). Innovative financial services are also emerging that can circumvent the need to transfer money. Higazi (as cited by Pieke, Van Hear, \& Lindley, 2007) mentions that among the Ghanaian diaspora, for example, an innovative scheme was being developed to provide medical insurance to enable migrants to finance both their own health care and that of relatives back home through contributions to a single scheme.

Regulation as a determining factor in the remittance channel chosen: Regulatory and policy factors exert important influence on the availability and accessibility of formal money transfer services and thus the range of remittance-sending channels available to migrants. Government policies and regulations of host countries, such as foreign exchange control, monetary policy, high tariffs and taxes, bureaucratic licensing process for financial institutions are some of the policies that play a role in popularity of informal channels (Sharif Mahmud, 2012). Informal remittance channels occupy monetary policy debates due to concerns about potential misuse for criminal ends, including money laundering, the financing of terrorism and smuggling. Moreover, they usually entail a higher risk of theft or loss as they often rely on informal contracts with little or no guarantees of enforcement. There are a number of ways in which regulation impacts the ability to send money formally (Bester, Hougaard, \& Chamberlain, 2010). Regulation causes documented and undocumented migrants to be ineligible for the formal channel of remittances and access to the financial system (Bester, Hougaard, \& Chamberlain, 2010). Remittance transfers through informal remittance service providers involve a minimum amount of paperwork which is often easier and more appealing for clients that lack the required documentation (Kosse \& Vermeulen, 2014). This creates a barrier to formalisation of remittances. It also has indirect effects through impacting on the cost and convenience of the transaction. The three most important regulatory barriers are the following:

- Exchange Control

- Anti-money Laundering Legislation

- Immigration Laws

Recent efforts are being made to loosen exchange control regulations in South Africa. Depending on which country the transaction is directed, different rules are expected to apply due to the common monetary area (CMA) agreements (Bester, Hougaard, \& Chamberlain, 2010). There are no trade and exchange restrictions between the member countries of the CMA, but this does not apply to non-residents transaction flows to nonCMA countries. Each of the CMA countries has its own exchange control regulations and authorities, and the application thereof must be at least as strict as that of South Africa. Implementing exchange control regulation requires the knowledge of the identity of the remitter, the issuing of authorised dealer licences and some reporting system requirements (Bester, Hougaard, \& Chamberlain, 2010).Anti-money laundering laws are targeting illicit flows that impact on the remittance market. In South Africa the anti-money laundering legislation is the Financial Intelligence Centre Act (FICA). A key obstacle for remittance formalisation is the FICA requirements for customers due to the required due diligence. In terms of this Act, before a financial institution can open an account or perform a single transaction for a customer, the bank must obtain the full name, date of birth, identity number or passport and the residential address of the person.

Immigration laws place a legal duty on financial institutions to ascertain the status or citizenship of the persons with whom they enter into commercial transactions, including the transfer of money. Documented and undocumented migrants face a further barrier to the rest of the financial system as they cannot proof their residence status and thus cannot access formal remittance channels (Bester, Hougaard, \& Chamberlain, 2010). Wage earners usually obtain work visas for a limited period, usually one year, with the hope that they can extent their visa for several years subsequently (Sharif Mahmud, 2012). On the other hand the money that they spent to go abroad is not covered by their salary of one year. If this Visa could not be extended they could not return to their home countries, otherwise they become illegal residents and do not have the documentary requirements to operate in the formal financial system (Sharif Mahmud, 2012). In the formal 
system, banks require clients to have a bank account, whereas Money Transfer Operators only require official identification, which forces some clients to use the informal channels (Kosse \& Vermeulen, 2014).

\section{Methodology}

A quantitative research design has been employed, to analyse migrant workers choice of sending cash or financial transfers from South Africa to other countries. The sample includes migrants seeking documentations from the Department of Home Affairs, migrants remitting at taxi ranks or bus terminals, and those remitting through official routes like commercial banks and money transfer operators. Approximately 350 questionnaires were administered to face-to-face respondents that were based mainly in the Gauteng province of South Africa and to others based in the eight other provinces. Only 295 responses were received in total including some by email. Some respondents did not complete the survey questionnaires and were removed during the data clean-up process. As such, only 275 responses were analysed. A Likert rating scale format (1-5) was used to allow a fair range of both positive and negative answer options (Albright, Winston, \& Zappe, 2009). The scale of 1 represents the highest/strongest opinion regarding agreement with the probing question and 5 the lowest. It is the most frequently used rating scale format in studies like this (Saunders, Lewis, \& Thornhill, 2009).

\section{Results}

Most of the migrant workers in South Africa originate from the Southern Africa Development Community (SADC) region. They are mainly Zimbabweans who make up 30 percent of the respondents. They are mostly aged between 21 and 45 . Respondents aged 26 to 35 represent 37 percent of the sample. More than 80 percent of the migrants have been in South Africa for at least a year, and about 30 percent of them have been in the country for three years or longer. Some studies report that migrants with higher education are less likely to use informal cash transfer channels, suggesting a potential role for financial education when attempting to increase the use of formal channels (Kosse \& Vermeulen, 2014). Siegel (2007) also finds that education has a very positive impact on the decision to remit formally. In our study, twenty percent of the respondents have no formal educational and 30 percent have a matric qualification.

Result of frequency of sending remittances: Cross border migrants from Southern Africa do not remit frequently from South Africa. Remittances are mostly carried out five to twelve times a year. Only about three percent remit annually. Less than three percent of sampled migrants remit cash on weekly basis. This is considered to be the exception rather than the rule.

Awareness of remittance channels: Two-thirds of the respondents are aware of a variety of remittance channels other than the one used at any particular time. This provides evidence that remitters are taking active economic decisions on the most appropriate remittance channel to use.

Results of the popularity of remittance channels: The use of Money Transfer Operators (MTOs) is the dominant means of sending money from South Africa, with the use of family and friends being about three percent less. The use of taxis, buses and trucks are in close proximity with the preference of banks. The Post Office and other means of sending remittances are the least popular of the channels used.

Table 3: Split of Formal and Informal remittance channel

\begin{tabular}{llll}
\hline Formal Remittances & Percent & Informal Remittances & Percent \\
\hline Bank & 18.5 & Taxi/ Bus/ Truck & 20.0 \\
Post Office & 7.3 & Family/ Friends & 24.7 \\
Money Transfer Operator & 28.0 & Other & 1.5 \\
Total & $53.8 \%$ & Total \% & $46.2 \%$ \\
\hline
\end{tabular}

Source: Survey Results

Descriptive Statistical Overview of Survey Results: The results show that most respondents are of the view thatregulatory or documentary requirements are an important factor influencing the choice of the remittance channel used. More than three-quarters of the respondents agree or strongly agree with the 
probing question.The mean response is 2.19 measured on the Likert scale. This falls below 3, indicating a string agreement with the probing question. The median is measured to be 2 , contributing to the importance of the mean response obtained. The standard deviation of 1.034 is low and indicates that the data points tend to be very close to the mean and thus there is not a lot of deviation from the mean score. The skewness is 1.244 indicating that it is skewed to the left. Thus individual scores would not greatly influence the mean. The Kurtosis is 1.349 indicating that the scores are closely grouped, and is within the acceptable reliable levels. The result is highly significant ( $\mathrm{p}$-value is 0.000 ), indicating a statistically proven relationship between the variables. We can conclude that regulatory or documentary requirements are an important factor determining the choice between formal and informal remittances. Furthermore, the mean is 2.19 indicating a strong agreement that regulation strongly influences the choice of remittance channel. The proposition is thus proven. This result is consistent with the literature in that there are a number of ways regulation impacts the ability to send money through the formal channels (Bester, Hougaard, \&Chamberlain, 2010). The requirement in the formal market causes documented and undocumented migrants to be ineligible for the formal channels of remittances and is a factor that influences the choice of remittance channel (Bester, Hougaard, \& Chamberlain, 2010). The regulatory requirements to prove the residential status of migrants place a further barrier to migrants to access formal channels (Bester, Hougaard, \& Chamberlain, 2010). (Kosse \& Vermeulen, 2014) indicate that remittance transfers through informal channels involve a minimum amount of paperwork and are easier for clients that do not have required documentations. Sharif Mahmud (2012) also mentions that other documentary requirements such as work visas are only issued for a limited period and if not extended migrants immediately become illegal residents and no longer possess the regulatory requirements to enter or operate within the formal financial system.

Table 4: Overview of Survey Results

\begin{tabular}{|c|c|c|c|c|c|c|c|}
\hline \multicolumn{8}{|c|}{ Statistics } \\
\hline & & & Mean & Median & Std. Deviation & Skewness & Kuntosis \\
\hline & Valid & Missing & & & & & \\
\hline The method you mostly use to send money depends on how much it will costyou & 275 & 2 & 1.7 & 1.00 & 1.027 & 1.599 & 2.234 \\
\hline $\begin{array}{l}\text { The method you mostly use to send money depends on the regulatory documents they } \\
\text { require from you }\end{array}$ & 275 & 2 & 2.1 & 2.00 & 1.034 & 1.244 & 1,349 \\
\hline $\begin{array}{l}\text { The method you mostly use to send money should be conveniently located for you, to have } \\
\text { easy access. }\end{array}$ & 275 & 2 & 2.0 & 2.00 & .992 & 1,328 & 1.869 \\
\hline $\begin{array}{l}\text { The method you mostly use to send money depends on how fast/quick my family can get the } \\
\text { money }\end{array}$ & 275 & 2 & 2.1 & 2.00 & 1.074 & 1,171 & 1.005 \\
\hline $\begin{array}{l}\text { The method you mostly use to send money depends on the use of technology, such as } \\
\text { cellphones, debitc cards and electronictransfers }\end{array}$ & 275 & 2 & 2.4 & 2.00 & 1.203 & .822 & -242 \\
\hline The method you mostly use to send money should be reliable and secure & 275 & 2 & 1.9 & 2.00 & 1.087 & 1.272 & 971 \\
\hline The method you mostly use to send money should be trustworthy. & 275 & 2 & 1.7 & 1.00 & 1.039 & 1.600 & 2.194 \\
\hline The method you mostly use to send money is famil lar or well-known to you. & 275 & 2 & 1.8 & 2.00 & 1.065 & 1.409 & 1,571 \\
\hline
\end{tabular}

Source: Survey Results 
Figure 1: Choice of remittance channel used is dependent on the regulatory or documentary requirements of the remittance channel

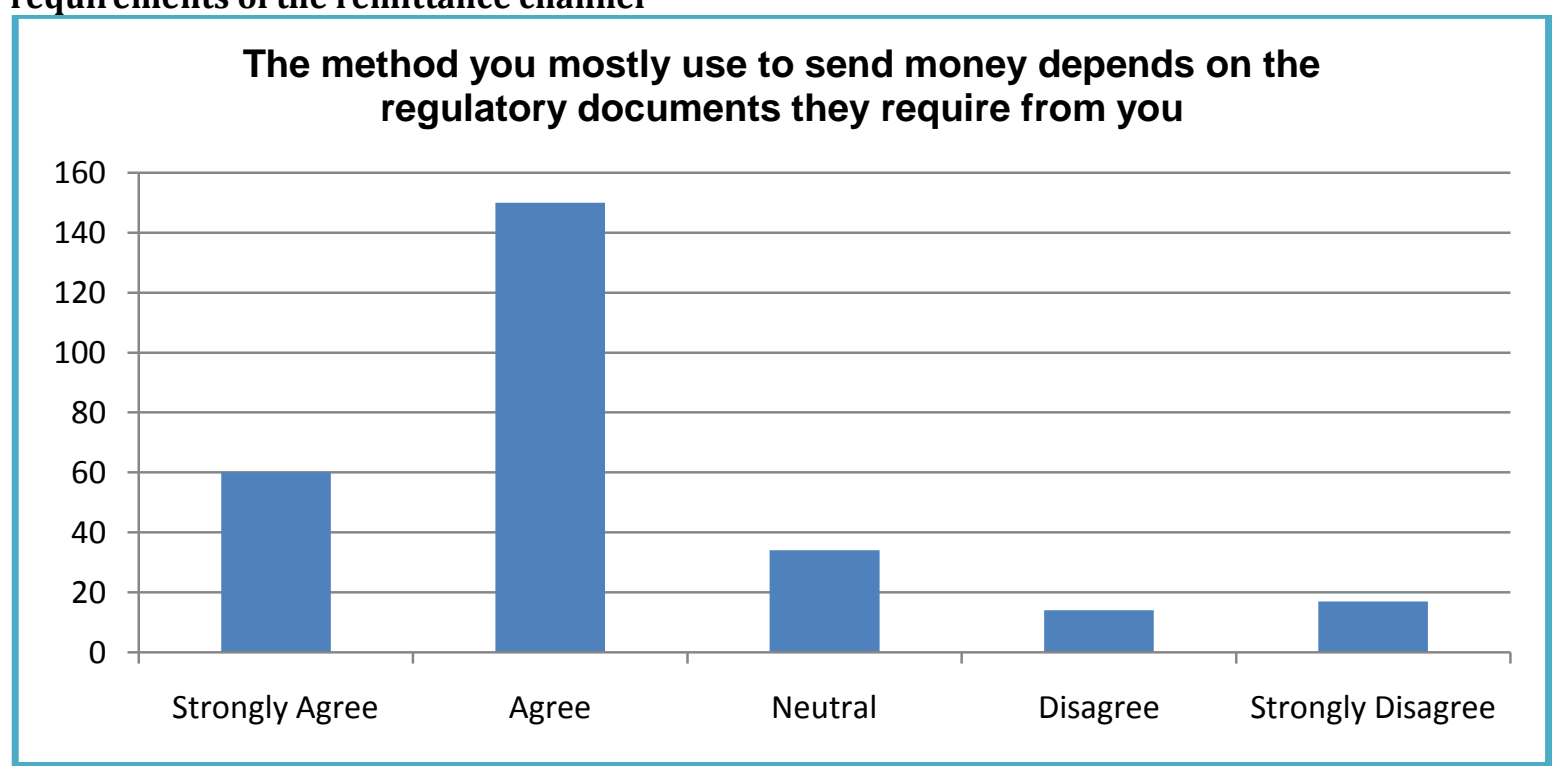

Impact of regulation on formal remittance channels: A rigid regulatory environment has made crossborder remittances very difficult, as financial regulations-like FICA, set onerous administrative requirements for foreign nationals and South Africans wishing to do cross-border mobile money transfers. Financial institutions are required, among others, to verify the background (full names, identity number), country of origin, proof of residence, South Africa's tax number, and source of a client's income as well as the source of the funds that the particular client expects to use in concluding the single transaction or transactions in the course of the business relationship. Remitting funds through the formal channels is also expensive. According to World Bank data, the global cost of remittances averaged around $8 \%$ of the amount transferred in the fourth quarter of 2014 (World Bank, 2015d). The cost of remittances in sub-Saharan Africa, however, far outstrips this at $12 \%$ of the transaction cost. According to World Bank data for the first quarter of 2015, the cost of sending cash through formal banking channels in South Africa averaged $20 \%$ of the value of remittances. The costs of sending money from South Africa to Zambia, Malawi, and Botswana are the most expensive in the region (World Bank, 2015b).Thus, in South Africa, mobile money services are undercutting banks when it comes to the cost of sending money to countries such as Zimbabwe. Money flowing to Zimbabwe forms one of the largest remittance corridors out of South Africa (Donelly, 2015). Operators such as "Mama Money" allow Zimbabweans living in South Africa to send money home through their cellphones at a rate of just under $5 \%$ of the total cost of the transaction.

\section{Conclusion}

Appropriate regulations can help increase migrants access to the formal financial system for these migrants. This can contribute to social upliftment, in not only South Africa, but also in the receiving countries. Also, the formalisation of remittances can also assist in preventing money laundering in a country. Results of this study suggest that regulatory and documentary requirements are important in driving the choice between formal and informal remittances have been consistent with the literature findings. South Africa has stringent foreign exchange rules to protect its reserves. As such the country's regulators prefer to have only banks dealing in money transfers. This follows their unfavourable experience with Western Union and its former incountry agency, Union African Money Transfer, which failed to comply with foreign exchange control regulations (Sander \& Maimbo, 2005).Regulations have created barriers to the flow of remittances, especially in the financial industry, where restrictive licensing of money transfer services limits the potential impact on remittances.South African regulators should assist the remittance sector in meeting regulatory compliance needs. This will encourage and support new immigrants in their newly established small business enterprises or employment sectors. 
Recently, in South Africa the Minister of Finance extended the business of designated foreign exchange transactions to Bureaux de Change institutions and authorised dealers with limited authority (Donelly, 2015). Money Transfer Operators can now operate by themselves and do not need a bank to partner with. Their business activities are restricted to that of money remittance services such as cross border person-to-person payments. In order to encourage remitters who use informal and risky channels to instead use formal ones, in June 2015, The South African Authorities relaxed the onerous regulations and financial institutions are no longer be required to obtain proof of residence or a South African tax number for cross-border transactions, provided the amount is less than R3 000 a day or R10 000 in a calendar month(Donelly, 2015).This notwithstanding, financial institutions must scrutinise the remittance activity on an on-going basis and use "enhanced measures, over and above normal procedures" to identify and report any suspicious activity. This would help curtail money laundering and improve security of funds transfer.

\section{References}

Acosta, P. A., Baerg, N. R. \& Mandelman, F. S. (2009). Financial development, Remittances, and Real exchange rate appreciation. Economic Review, 94(1), 1-12.

Akinboade, O.A. \& Kinfack, E.C. (2012). Regulation, Awareness, compliance and SME Performance in Cameroon's manufacturing and retail sectors. International Journal of Social Economics, 39(12), 933 950

Albright, S. C., Winston, W. L. \& Zappe, C. (2009). Data analysis and decision making (3rd Ed.). Mason: Thomson South Western.

Ambrosius, C., Fritz, B. \& Stiegler, U. (2008).Capitalising on remittances for financial development - examples of regulations and policies. Retrieved from Migration Policy: https://www.lai.fuberlin.de/homepages/fritz/publikationen/EADI_remittances_finalpaper.pdf

Anyanwu, J. C. \& Erhijakpor, A. E. (2010). Do International Remittances Affect Poverty in Africa? African Development Review, 22(1), 51-91.

Bester, H., Hougaard, C. \& Chamberlain, D. (2010).Reviewing the policy framework for money transfers. Cape Town: Centre for Financial Regulation \& Inclusion.

Better Regulation Task Force (BRTF) (2003). Principles of Good Regulation. Available athttp://www.brtf.gov.uk/taskforce/reports/PrinciplesLeaflet.pdf, accessed on 31-03-2009

Bouoiyour, J. \&Miftah, A. (2015).Why do migrants remit? Testing hypotheses for the case of Morocco.IZA Journal of Migration, 4(2), 1-20.

Bracking, S. \& Sachikonye, L. (2010).Migrant Remittances and Household Wellbeing in Urban Zimbabwe. International Migration, 48(5), 203-227.

Daseman, A. (2013). Factors driving the choice between formal and informal cross border remittances Masters of Business Administration Dissertation submitted to the Gordon Institute of Business Science, University of Pretoria, November 2013

Donelly, L. (2015). Sending money out of SA set to become easier and cheaper, Mail and Guardian, 9 June, available at http://mg.co.za/article/2015-06-09-sending-money-out-of-sa-set-to-become-easierand-cheaper, accessed 14-12-2016

Kosse, A. \& Vermeulen, R. (2014).Migrants' Choice of Remittance Channel: Do General Payment Habits Play a Role? World Development, 62(c), 213-227

Kotze, H. \& Hill, L. (1997). Emergent Migration Policy in a democratic South Africa. International Migration, 35(1), 5-35

Lucas, R. E. \& Stark, O. (1985).Motivations to Remit: Evidence from Botswana. Journal of Political Economy, 93(5), 901 - 918.

Maharaj, B. (2009). Migrants and urban rights: politics of xenophobia in South African cities. L'espace Politique, 8(2), 1-10. Available at https://espacepolitique.revues.org/1402?lang=en, accessed on 10-12-2016

Maphosa, F. (2005).The impact of remittances from Zimbabweans working in South Africa on rural livelihoods in the southern districts of Zimbabwe. University of Zimbabwe, Department of Sociology. Johannesburg: University of Witwatersrand.

Mookerjee, R. \& Roberts, J. (2011).Banking services, transaction costs and international remittance flows. Applied Economics Letters, 18(3), 199-205

Organisation for Economic Co-operation and Development (OECD). (1994). The OECD Reference Checklist for Regulatory Decision-making: A Draft Recommendation of the OECD”, PUMA (OECD, Paris) 
Organisation for Economic Co-operation and Development (OECD). (2003). Privatising State-Owned Enterprise, an Overview of Policies and Practices in OECD Countries, OECD, Paris.

Peberdy, S. (2010).Setting the scene: Migration and urbanisation in South Africa. Synthesis Report for the Atlantic Philanthropies.

Pieke, F. N., Van Hear, N. \& Lindley, A. (2007). Beyond Control? The mechanics and dynamics of 'informal' remittances between Europe and Africa. Global Networks: A Journal of Transnational Affairs, 7(3), 348-366.

Puri, S. \& Ritzema, T. (1999).Migrant worker remittances, micro-finance and the informal economy: Prospects and Issues. Geneva: International Labor Organization.

Radlicki, M. (2015). The 30m-strong Africa diaspora likely sends $\$ 160 \mathrm{bn}$ home every year: Where does it go? Mail and Guardian, available at http://mgafrica.com/article/2015-05-29-remittance-in-africawhere-does-it-go. Accessed 12-12-2016

Ratha, D. \& Xu, Z. (2008).Migration and Remittances Factbook 2008.Washinton DC: World Bank.

Ruiz, I. \& Vargas-Silva, C. (2009).To send, or not to send: that is the question. A review of the literature on workers' remittances. Journal of Business Strategies, 26(1), 73-98.

Sander, C. (2004).Passing the Buck in East Africa: The Money Transfer Practice and Potential for Services in Kenya, Tanzania, and Uganda. MicroSave-Africa, Nairobi.www.microsave.org.

Sander, C. \& Maimbo, S.M. (2005).Migrant Remittances in Africa: A Regional Perspective, in Maimbo Samuel Munzele and Dilip Ratha (eds)Remittances Development Impact and Future Prospects, Chapter 2,The World Bank, Washington DC.

Saunders, M., Lewis, P. \& Thornhill, A. (2009).Research methods for business students (5th Ed.). Pearson: Prentice Hall.

Segatti, A. (2011a). Migration to South Africa: Regional challenges versus national instruments and interests. In A. Segatti, \& L. B. Landau, Contemporary migration to South Africa: A regional development issue (pp. 9 - 30). Washington: The World Bank.

Segatti, A. (2011b). Reforming South African immigration policy in the post apartheid period (1990 - 2010). In A. Segatti, \& L. B. Landau, Contemporary migration to South Africa: A regional development issue (pp. 31 - 66). Washington: The World Bank.

Sharif Mahmud, A. S. (2012).Determinants behind the use of informal channels for remitting money from overseas by the wage earners of Bangladesh. Thailand: Asian Institute of Technology, School of Management.

Siegel, M. (2007).Immigrant integration and remittance channel choice. Maastricht University. Maastricht: Maastricht Graduate School of Governance.

Siegel, M. \& Lucke, M. (2009).What determines the choice of transfer channel for migrant remittances? The case of Moldova. Germany: Kiel Institute for the World Economy.

Statistics South Africa. (2015).Documented immigrants in South Africa, 2013, Statistical release P0351.4, Pretoria

Statistics South Africa. (2012a). Documented immigrants in South Africa, 2011. Statistical release D0351.4, Pretoria

Statistics South Africa. (2012b). Census 2011: Migration Dynamics in South Africa, Report No. 03-01-79 Pretoria

Taylor, J. E.\& Fletcher, P. L. (2007).Rural Economies of the AmericasProgram. Retrieved April 16, 2012, from US Davis Univeristy of California: http://www.reap.ucdavis.edu/research/volume2

Truen, S. \& Chisadza, S. (2012). The South Africa -SADC remittance channel' Prepared by DNA Economics for FinMark Trust, Pretoria. Available at http://cenfri.org/documents/Remittances/2012/ The\%20South\%20Africa-SADC\%20remittance\%20channel_Report.pdf, accessed on 08-Dec 2016.

Truen, S., Ketley, R., Bester, H., Davis, B., Hutcheson, H. D., Kwakwa, K. \& Mogapi, S. (2005). Supporting remittances in Southern Africa: Estimating market potential and assessing regulatory obstacles. Prepared by Genesis Analytics for CGAP and FinMark Trust

Van Eyden, R., Owusu-Sekyere, E. \& Kemegue, F. (2011).Remittance inflows to Sub-Saharan Africa: The case of SADC. Department of Economics. Pretoria: University of Pretoria.

World Bank. (2015a).Migrants and Development Brief, Migration and Remittances Team, Development Prospects Group, Brief No. 24, Washington DC.

World Bank. (2015b).Migration and Remittances Recent Developments and Outlook, Migrants and Development Brief, No. 25, Washington DC 
World Bank. (2015c). Remittances growth to slow sharply in 2015, as Europe and Russia stay weak; pick up expected next year, Washington DC. USA, available at http://www.worldbank.org/en/news/pressrelease/2015/04/13, accessed 12-12-2016

World Bank. (2015d). The Cost of Sending Remittances: June 2015 Data, Issue No. 14, Washington DC. USA, available at http://www.worldbank.org/en/topic/paymentsystemsremittances/publication/costsending-remittances-june-2015-data, accessed 12-12-2016

World Bank. (2016).Migration and Remittances Factbook, Third Edition, Washington DC, USA 